КОПИТОВА О.С.

\title{
ПЕРСПЕКТИВИ ЗАБЕЗПЕЧЕННЯ ЄДНОСТІ СУДОВОГО ПРАВОЗАСТОСУВАННЯ В УМОВАХ ТРАНЗИТНОГО ЗАКОНОДАВСТВА
}

\author{
PROSPECTS OF ENSURING UNITY JUDICIAL ENFORCEMENT \\ IN CONDITIONS TRANSIT LEGISLATION
}

Стаття присвячена дослідженню проблеми досягнення єдності судового правозастосування у період транзитності законодавства, адже згідно із принципом вірності Конституції рішення судів мають грунтуватися на верховенстві права і вирішенням справи досягати такого верховенства. Цього, на жаль, складно досягти країнам перехідної демократії чи країнам перехідного періоду, зокрема Україні.

Метою є розкриття перспектив забезпечення єдності судового правозастосування в умовах транзитного законодавства. Методи дослідження: порівняльно-правовий, діалектичний, метод моделювання, синтезу й формально-логічний методи.

Результати дослідження. Обгрунтовується, що забезпечення єдності судового правозастосування у період транзитності законодавства вимагає консолідованої діяльності усіх публічних інституцій України, а не лише судів. Доведено, що конституційний принцип рівності прав передбачає однакове застосування правової норми. У багатьох постановах ВП ВС, рішення в яких можуть мати загальне значення для судової практики, здебільшого постають такі проблеми, які не мають свого розв'язання лише у приписах чинного законодавства та інших джерел. Доведено, що такі проблеми потребують обгрунтування за допомогою доктринальних засобів і врахування соціальних (позаюридичних) аргументів.

Обгрунтовується необхідність законодавчого врегулювання виключної проблеми, яку у правовій площині ВС розв'язав, однак ця проблема не зникла. Зауважується про необхідність початку й налагодження неформального діалогу у вигляді певних спільних нарад, а не тільки конференцій, круглих столів тощо, на яких будуть обговорюватися питання забезпечення єдності розуміння правових норм на першому етапі подолання перехідної юстиції в Україні, зважаючи на кардинально протилежні реформи останніх років.

Ключові слова: верховенство права, судове правозастосування, Верховний Суд, виключна правова проблема, транзитне законодавство, перехідна юстиція.

The article is devoted to the study of the problem of achieving unity of judicial law enforcement in the period of transit of legislation, because according to the principle of fidelity to the Constitution, court decisions must be based on the rule of law and resolve such rule of law. Unfortunately, this is difficult to achieve for countries in transition or countries in transition, in particular Ukraine.

The goal is to reveal the prospects of ensuring the unity of judicial enforcement in the conditions of transit legislation. Research methods: comparative legal, dialectical, method of modeling, synthesis and formal-logical methods.

Research results. It is substantiated that ensuring the unity of judicial enforcement in the period of transit of legislation requires the consolidated activities of all public institutions of Ukraine, not just the courts. It is proved that the constitutional principle of equality of rights presupposes equal application of a legal norm. In many decisions of the

(C) КОПИТОВА О.С. - кандидат юридичних наук, суддя (Північний апеляційний господарський суд), старший науковий співробітник відділу організації наукової діяльності та захисту права інтелектуальної власності (Національна академія внутрішніх справ) https://orcid.org/0000-0001-7759-5960 
Supreme Court, decisions in which may be of general importance for judicial practice, there are mostly such problems that do not have their solution only in the provisions of current legislation and other sources. It is proved that such problems need to be substantiated by doctrinal means and taking into account social (non-legal) arguments.

The necessity of legislative settlement of the exclusive problem, which was solved by the Supreme Court in the legal plane, is substantiated, but the problem itself has not disappeared. It is noted that informal dialogue should be initiated and established in the form of certain joint meetings, not only conferences, round tables, etc., which will discuss the unity of understanding of legal norms in the first stage of overcoming transitional justice in Ukraine, given the radically opposite reforms of recent years.

Key words: rule of law, judicial enforcement, Supreme Court, exclusive legal issue, transit legislation, transitional justice.

Вступ. Період, який нині проживає Україна, називається перехідним. Швидкоплинні трагічні події останніх років впливають на соціальний зміст держави, роблячи його все більш строкатим, фрагментарним і поляризованим. Це є нічим іншим як загостренням перехідних процесів, які зумовлюють відмову від консервативного демократичного транзиту, що вичерпав себе на етапі встановлення «фасадної» демократії [9, с. 219].

Загалом країни перехідного періоду характеризуються різноманітністю політичних подій, а також кількістю постійно впроваджуваних реформ. Їх ще можна визначити як країни «транзитного суспільства». Під час цього періоду яскраво простежується «транзит влади» і, що особливо небезпечно (однак $є$ природною рисою такого суспільства), «транзитність законодавства». ООН транзитними визначає постконфліктні суспільства, суспільства, які зазнали репресій і потребують поновлення верховенства права, примирення у зв'язку із широкомасштабними порушеннями прав людини в умовах інституціональної кризи та кризи ресурсів, що вичерпуються, зниженою безпекою та проблемами розколу населення $[2 ; 4$, с. 534] за різними ознаками.

М.В. Савчин справедливо наголошує, що «країни перехідної юстиції, якою нині є Україна, потребують встановлення справедливих правил гри і ефективних владних установ. Тому належне функціонування інститутів публічної влади розглядається як важливий фактор забезпечення прав людини [18]. Це можливо, якщо конституційна система грунтується на наступності правил, процедур та інститутів.

Без континуїтета, тобто безперервності конституційної традиції, нація може опинитися на межі виживання. Континуїтет досягається шляхом формування і збереження правил, в основі яких - повага прав людини і обмеження влади заради запобігання свавіллю і тиранії. Такі правила повинні відтворюватися і примножуватися в постійній практиці діяльності органів публічної влади і приватних осіб [18]. Отже, безперервність конституційної традиції впливає на правонаступність законодавства, що особливо потрібно під час захисту прав, свобод та інтересів людини і громадянина й інших учасників суспільних відносин.

Згідно із принципом вірності Конституції рішення судів мають грунтуватися на верховенстві права і вирішенням справи досягати такого верховенства. Цього, на жаль, складно досягти країнам перехідної демократії чи країнам перехідного періоду, зокрема й Україні.

Питанням єдності судового правозастосування, в тому числі через судову правотворчість в Україні та країнах континентальної системи права, періодично приділяли увагу вчені Є.Г. Бобрєшов, С.Л. Дегтярев, А.Г. Карапетов, М.І. Козюбра, С.П. Головатий, Л.А. Луць, Б.В. Малишев, А.В. Малько, Н.М. Марченко, Н.М. Оніщенко, С.П. Погребняк, Н.В. Стецик, С.В. Шевчук та інші. Водночас ця проблема після судової реформи щодо правосуддя 2016 року, яка дала активний старт транзитності законодавства, а також прийняття процесуальних кодексів у новій редакції 2017 року ще не отримала належного наукового пізнання на загальнотеоретичному монографічному рівні. У межах цієї статті спробуємо заповнити цю прогалину.

Постановка завдання. Метою статті є розкриття перспектив забезпечення єдності судового правозастосування в умовах транзитного законодавства.

Результати дослідження. Питання транзитного правосуддя (Transitional Justice) концептуально розкрили О.З. Хотиньска-Нор і Л.М. Москвич при дослідженні ролі довіри в легітимації правосуддя у країнах транзитного періоду [4, с. 533-543]. Традиційно суд як інститут державної влади виступає головним легальним суб'єктом захисту прав людини. В країнах розвиненої демократії його легітимність і незалежність не ставиться під сумнів. У той же час транзитне 
суспільство характеризується глобальними соціокультурними трансформаціями. Цей період відрізняється розбіжністю темпів інституційних перетворень і змін у нормах, цінностях і способах поведінки людей. Дисонанс формальних і неформальних норм породжує кризові явища, які призводять до застою розвитку демократії і суспільства. Такою $є$ криза довіри до органів держави, у тому числі й до суду [4, с. 533-534].

Навіть побіжно проаналізувавши усі суспільні події незалежної України, слід констатувати, що часті суспільно-політичні і революційні події останніх 15 років у нашій державі, зміни конституційного устрою та перманентні суперечливі реформи у сфері права (перехідна юстиція) не дозволили Україні стати країною розвиненої економіки. Це також стало причиною суттєвої міграції населення країни. Важливим при цьому є те, що перманентні суперечливі реформи й міграція є не тільки невід'ємними ознаками країн перехідного періоду, а й негативними передумовами для порушень прав людини.

Також необхідно враховувати сплеск науково-технічного прогресу, який зумовлює постійну трансформацію суспільних відносин і появу абсолютно нових, наприклад застосування криптовалюти як виду платежу, впровадження елементів штучного інтелекту у суспільні відносини, необхідність правового регулювання застосування нанотехнологій у медичній сфері тощо. Право як універсальний регулятор має встигати здійснювати належне упорядкування нових і новітніх суспільних відносин.

Завжди слід пам'ятати про ординарні, базові суспільні відносини з тисячолітньою правовою охороною (відносини безпеки життя і здоров'я, власності, конституційні свободи, питання взаємодії гілок влади тощо), що теж не залишаються незмінними. Такі відносини також розвиваються, а іноді навіть мутують [3, с. 7], тобто може відбуватися викривлення їх сутності залежно від запитів суспільства в певний період часу.

Незалежно від рівня розвитку країни, писаний закон ніколи не встигає своєчасно реагувати на нормативне врегулювання усіх суспільних відносин. Здебільшого спочатку реагує практика, створюючи звичаї, окремі з яких можуть трансформуватися у так звані «санкціоновані звичаї», тому саме практика формує власне бачення майбутнього нормативного регулювання.

Додатковими проблемами країн перехідного періоду (країн «транзитного суспільства») є нестабільність і непрогнозованість законодавства, постійна мінливість запиту суспільства, діаметральні цілі суспільства і влади. Тому, звертаючись до суду, позивач не завжди може отримати ефективний захист свого суб'єктивного права в межах виключно одного виду судочинства [7]. Особливо цей процес характерний для сфер гарантування та забезпечення основних (фундаментальних) прав людини, в тому числі і в сфері різноманітних приватноправових відносин.

Також необхідно вказати на постійне ускладнення системи і структури правовідносин під час захисту прав і свобод осіб судами. Проблема посилюється, коли певні галузеві права також є основними (фундаментальними) і одночасно підлягають конституційній охороні й захисту. У зв'язку з цим прагнення захистити своє порушене суб'єктивне право формує необхідність ініціативи не тільки судового захисту прав і свобод людини і громадянина та інших учасників суспільних відносин, а й ініціювання конституційного провадження за конституційною скаргою визначених законом осіб (ч. 4 ст. 55 Конституції України).

Завершується судовий захист навіть після розгляду конституційної скарги КСУ із формуванням конституційно-правового змісту норми закону чи без такого у суді шляхом ухвалення остаточного вирішення судового спору на національному рівні. Таке вирішення з позиції судового правозастосування зводиться до розв'язання проблеми як саме (яким чином) суд застосовує ті чи інші приписи закону (виділено нами - O.К.) під час перегляду судової справи.

Особлива складність нинішніх реалій судового правозастосування полягає у тому, що норми права як основа вирішення справи отримують періодичні зміни або можуть їх очікувати (наприклад, зареєстровані законопроекти діаметрально протилежного змісту) тощо. Законодавство, на підставі якого суд вирішує справу і застосовує його норми, часто змінюється не за потребами часу, а залежно від політичної доцільності чи перманентних реформ, інколи заради реформ. Часом унаслідок мінімальних семантичних змін норми права можуть трансформуватися у глибоко смисловому розумінні.

Негативною новелою законотворчої техніки останніх п’яти років стало викладення законів у нових редакціях замість прийняття нового законодавчого акта. При цьому законодавець не обмежився тільки актами матеріального права. У 2017 році ВРУ по суті прийняла всі нові правила судових процесів у порядку ГПК України, КАС України, ЦПК України, виклавши нову редакцію цих процесуальних кодексів і побудувавши іiі на максимально уніфікованих засадах. 
Тобто процесуальні кодекси були викладені як закон у редакції закону. Також було прийнято низку нових законів, які стосуються останньої стадії захисту прав осіб, зокрема Закон України «Про виконавче провадження» [11], Закон України «Про органи та осіб, які здійснюють примусове виконання судових рішень і рішень інших органів» [12] тощо. Ці акти, окрім норм матеріального права, містять у собі чималу кількість норм процесуального значення.

На жаль, механізм втілення вказаних процесуальних кодексів (через два тижні після набрання ними чинності) для судів першої і апеляційної інстанцій, які розглядають і переглядають судові справи у повному обсязі паралельно з існуванням надзвичайно високого навантаження, створив засади правової невизначеності не тільки для суддів та юридичної спільноти, а й для будь-якого пересічного громадянина як учасника найближчих судових проваджень 3 початку набрання чинності новими редакціями кодексів. Це сталося, зокрема, у зв'язку з тим, що процесуальні кодекси у новій редакції нині містять застереження про те, що «справи у судах першої та апеляційної інстанцій, провадження у яких відкрито до набрання чинності цією редакцією Кодексу, розглядаються за правилами, що діють після набрання чинності цією редакцією Кодексу» (п.п. 9 п. 1 р. I «Перехідні положення» ГПК України, п.п. 9 п. 1 р. I КАС України, п.п. 9 п. 1 р. І ЦПК України) [8].

Законом № 2147-VIII не було встановлено достатнього проміжку часу насамперед для суддів першої та апеляційної інстанцій опанувати весь комплекс нових процесуальних правил розгляду судових справ у різних юрисдикціях. Також юридична спільнота й громадськість не мали об'єктивної можливості належним чином пристосуватися до нових умов правового регулювання. Примітним є те, що попередня законотворча діяльність ВРУ стосовно кодифікованих актів враховувала строк відтермінування у межах від півроку до року з моменту прийняття до набрання чинності кодексами.

Розмірковуючи над можливостями уніфікувати судове правозастосування в період транзитного законодавства, слід зауважити, що нещодавно КСУ висловив позицію про необхідність розумного часового проміжку між офіційним оприлюдненням закону і набранням ним чинності. Так, у рішенні від 15 квітня 2020 року № 2-р(II)/2020 [17] КСУ зазначив, що в контексті принципу верховенства права важливим є встановлення при внесенні змін до законодавства розумного часового проміжку між офіційним оприлюдненням закону і набранням ним чинності.

Конституційний Суд України у рішенні від 22 травня 2018 року № 5-p/2018 наголошував, що принцип верховенства права передбачає внесення законодавчих змін із визначенням певного перехідного періоду (розумного часового проміжку між офіційним оприлюдненням закону і набранням ним чинності), який дасть особам час для адаптації до нових обставин; тривалість перехідного періоду у разі зміни юридичного регулювання суспільних відносин має визначати законодавець у кожній конкретній ситуації з урахуванням таких критеріїв: мети закону в межах правової системи і характеру суспільних відносин, які ним регулюються; кола осіб, до яких застосовуватиметься закон, і їх здатності підготуватися до набрання ним (його новими положеннями) чинності; інших важливих обставин, зокрема тих, що визначають час, необхідний для набрання чинності таким законом (абз. 5 п.п. 4.1 п. 4 мотивувальної частини) [17].

Конституційний Суд України посилається на те, що зміни в юридичному регулюванні має бути вчинено так, щоб особи, юридичного статусу яких такі зміни стосуються, мали реальну можливість пристосуватися до нової юридичної ситуації, зокрема встигли реалізувати певні права (вчинити потрібні дії) у спосіб, встановлений законодавством до внесення відповідних змін. За певних обставин, зокрема, якщо нове законодавче регулювання погіршуватиме юридичний статус осіб, законодавець повинен передбачити достатній перехідний період (розумний часовий проміжок) із моменту опублікування закону до набрання ним чинності (початку його застосування), протягом якого зацікавлені особи мали б можливість підготуватися до виконання вимог, передбачених новим законодавчим регулюванням» (п. 4.1. мотивувальної частини рішення від 15 квітня 2020 року № 2-p(II)/2020) [17]. Викладене дає підстави для висновку, що законодавець, виклавши у 2017 році процесуальні кодекси у новій редакції (по суті це були нові процесуальні акти, якими суддя має керуватися у своїй діяльності), створив усі умови і для транзитності сучасного процесуального законодавства.

Вказане обгрунтовується тим, що всі процесуальні акти нині діють як закон у редакції закону, що створює істотну незручність під час використання конкретного кодексу для вивчення спірної ситуації учасниками судових процесів залежно від стадії оскарження справи і встановлення процесуальних правил, які діяли в цей період під час реалізації, участі вказаних осіб у реалізації права на судовий захист тощо. 
Не меншу складність спочатку викликали і правила застосування судами новел процесуальних кодексів. Слід нагадати, що будь-який законодавчий акт здебільшого складається із трьох складників: 1) преамбула (сфера дії закону, коло осіб, на яких поширюється дія тощо - не в усіх законах); 2) основні положення (правила для суб'єктів права, на яких поширюється дія закону); 3) прикінцеві та перехідні положення (що відповідають за порядок і умови імплементації основних положень і не можуть створювати нових правил поведінки).

Викладення процесуальних кодексів у новій редакції насамперед створило плутанину із дією норм права в часі, оскільки п.п. 9 п. 1 р. I «Перехідні положення» ГПК України, п.п. 9 п. 1 р. I «Перехідні положення» КАС України, п,п. 9 п. 1 р. I «Перехідні положення» ЦПК України створювали колізії із загальними засадами здійснення судочинства судами і дією законодавства про господарське / адміністративне / цивільне судочинство (ч. 3 ст. 3 ГПК України, ч. 3 ст. 3 КАС України, ч. 3 ст. 3 ЦПК України): «Провадження в цивільних справах здійснюється відповідно до законів», чинних на час вчинення окремих процесуальних дій, розгляду і вирішення справи (виділено нами - O.K.).

Відбулася внутрішня колізія між основними і перехідними приписами процесуальних актів, розв'язання якої спочатку набуло дуалістичного характеру: певні суди (судді) завершували розгляд окремих процесуальних дій у справі за старими редакціями кодексів, а окремі - відразу здійснювали розгляд за новими, що інколи призводило до повернення розгляду справи на попередню стадію (так, у позовному провадженні відбувалося повернення на стадію підготовчого засідання тощо).

Отже, суди перших і апеляційних інстанцій вкінці календарного 2017 року, окрім істотного навантаження на кожного суддю першої та апеляційної інстанцій стикнулися із проблемою правильного (виділено нами - O.K.) застосування норм процесуального права 3 метою недопущення ïх порушення. Логічним наслідком порушення норм процесуального права може бути оскарження такого рішення до судів вищих інстанцій із імовірним одночасним ініціюванням дисциплінарного провадження щодо судді. Важливим при цьому є той факт, що суддя де факто перебуває в умовах неправильної законодавчої політики держави і має застосовувати такий закон, який $є$.

Ситуація ускладнюється, коли норми законів формують законодавчу множинність процесуальних дій судді, що також порушує правову визначеність. Йдеться не про судовий розсуд судді стосовно дискреції варіативності застосування норм матеріального права, на підставі якої вирішується спір. Прогнозованість не тільки матеріального, а й процесуального законодавства, чіткість та ясність процесуальних норм права $є$ складниками правової визначеності як конституційного елементу правової впевненості судді насамперед щодо власної судової незалежності при вчиненні тих чи інших процесуальних дій. Оскільки в інакшому, як справедливо наголошує Ханс Петер Гравер, «суддя перебуває під тиском, коли законодавчий орган атакує право» [1, с. 222].

Закони приймаються з метою виконання їх приписів учасниками різноманітних суспільних відносин. Особа, відчуваючи і розуміючи несправедливість закону чи його окремих положень, зокрема на стадії виконання їх приписів, може реалізувати згідно із ч. 6 ст. 55 Конституції України будь-який незаборонений законом спосіб захищати свої права і свободи від порушень і протиправних посягань.

Звернення до суду у різних формах (найчастіше у позовному порядку) при цьому є найбільш поширеним і дієвим способом захисту. Свого часу КСУ на підставі ст. 3 Конституції України сформулював твердження про те, що «судовий спосіб захисту вважається найбільш дієвою гарантією відновлення порушених прав та свобод людини і громадянина» (абз. 1 п.п. 3.2. п. 3 мотивувальної частини рішення Конституційного суду України від 9 вересня 2010 року № 19-рп/2010).

Тому наведений нами сучасний стан транзитності законодавства $€$ ілюстрацією щоденних умов діяльності судді по застосуванню норм права під час здійснення правосуддя, оскільки майже кожного дня суд «як хранитель правових норм» змушений вирішувати «рівняння з багатьма невідомими», коли «невідомими» $е$ «постійно перемінні норми права». На жаль, сучасний розвиток України ілюструє вже звичне ставлення до такого стану як до умовної «константи», що не сприяє єдності судової практики. Це ще раз підкреслює важкість як забезпечення єдності судового правозастосування в умовах транзитного законодавства в Україні, так і забезпечення незалежності судді під час здійснення правосуддя. Адже саме незалежність судової влади є поширеним і важливим інструментом досягнення верховенства права [6, с. 272].

О.3. Хотинська та Л.М. Москвич наголошують, що чим більш незалежно й відкрито можуть діяти суди, тим більший їх вплив на зміни в суспільстві і функціональність демократичних інститутів. Публічність судових розглядів у контексті «перехідного правосуддя» має важливе зна- 
чення для цього процесу. У той же час саме незалежність судової влади та верховенство права $\epsilon$, можливо, найскладнішими механізмами створення і консолідації молодих демократій. Ризик полягає у тому, що протягом перших років після зміни режиму (у статті йдеться про репресивний чи авторитарний режим - O.K.) суд як інструмент перехідного правосуддя може бути використаний для легітимації нової політичної еліти і політичного порядку [4, с. 536].

Перехідна юстиція в Україні вимагає справедливих правил і забезпечення верховенства права. Наша країна - не єдина держава, яка прагне подолати власний перехідний період і стати країною розвиненої демократії. П. Гаудер, розмірковуючи над розвитком верховенства права у реальному світі, наводить цікаву для цілей нашого дослідження цитату Карлоса Сантіно (яку в подальшому він критикував за розуміння верховенства права в суто інструментальному підході) [6, c. 258-259].

Карлос Сантіно зазначав про розвиток верховенства права в Латинській Америці таке: «Хоча швидке і наполегливе ухвалення рішень, необхідних для реалізації ринкових реформ першого покоління, часто потребує гнучкої судової системи, економічні реформи другого покоління, спрямовані на закріплення інституційних основ ринкової економіки, потребують абсолютно протилежного. Ринково орієнтовані економічні реформи не матимуть стійкого характеру без відновлення і зміцнення довіри до верховенства права. Зі зростанням надійності юридичних і судових процедур зміцнюється довіра й до процесу ухвалення політичних рішень. На більш загальному рівні можна сказати, що управління за допомогою актів виконавчої влади, яке розглядається як цінний актив на початковому етапі економічних реформ, на другому етапі реформ перетворюється на тягар» $[5$, с. $119 ; 6$, с. 258-259].

На наш погляд, правова система України нині перебуває на першому рівні, коли, незважаючи на демократичні гасла, інші гілки влади вимагають гнучкої судової системи, забезпечення єдності судової практики і прогнозованості судового правозастосування. Втручання інших гілок влади у судову є очевидним і неприхованим, що не сприяє єдності судового правозастосування. Враховуючи наведене, а також умови транзитного законодавства, мусимо констатувати, що єдність судового правозастосування буде тимчасовою, нестійкою і, на жаль, ситуативною.

Нагадаємо, що саме на ВС як на найвищий суд у системі судоустрою України покладено основне завдання - забезпечувати сталість та єдність судової практики, зокрема прецедентної практики ВС, шляхом прийняття рішень, які мають загальне значення для судової практики. ВП $\mathrm{BC}$ повинна сприяти єдності такої практики, усуваючи її різнобій. Відступлення від власних попередніх висновків без належного обгрунтування й мотивації не сприяє єдності судового правозастосування.

Прикладом, зокрема, є висновки щодо застосування норм права ВП ВС у справі № 916/3006/17 [10]: «80. Велика Палата Верховного Суду вважає, що строк для звернення до нотаріуса за вчиненням виконавчого напису, передбачений ст. 88 Закону України «Про нотаріат», безпосередньо пов'язаний із позовною давністю, встановленою ЦК України. Загальна позовна давність встановлюється тривалістю у три роки (ст. 257 ЦК України).

Отже, загальний строк для звернення стягувача до нотаріуса за вчиненням виконавчого напису становить не більше трьох років із дня виникнення у стягувача права вимоги до боржника незалежно від суб'єктного складу сторін у правовідносинах, тобто цей строк підлягає застосуванню й у відносинах між юридичними особами. Якщо для вимоги, за якою видається виконавчий напис, законом встановлено іншу позовну давність, виконавчий напис видається у межах цього строку.

81. Велика Палата Верховного Суду відступає від висновку, викладеного у постанові Верховного Суду від 17 травня 2018 року у справі № 307/1580/17, щодо застосування положень ч. 2 ст. 88 Закону України «Про нотаріат», зокрема про те, що ця норма не обмежує трирічним строком нарахування заборгованості, на стягнення якої вчиняється виконавчий напис, за умови встановлення сторонами відповідно до ст. 259 ЦК України збільшеної позовної давності для відповідної вимоги, оскільки вважає, що зазначений строк не можна змінити домовленістю сторін» [10].

Відступлення від попереднього висновку ВС і формування нової правової позиції ВП ВС стало підставою для звернення Товариства з обмеженою відповідальністю «Укркава» до КСУ із конституційною скаргою про визнання такою, що суперечить Конституції України, ч. 1 ст. 88 Закону України «Про нотаріат» [17].

1 липня 2020 року Перший Сенат КСУ визнав цю норму закону такою, що відповідає Основному Закону України, виклавши у мотивувальній частині такі аргументи: «Конституційний Суд України вважає, що положення ч. 1 ст. 88 Закону, відповідно до яких нотаріус вчиняє 
виконавчі написи за умови, що з дня виникнення права вимоги минуло не більше трьох років, $a y$ відносинах між юридичними особами - не більше одного року (виділено нами - O.К.), є чіткими, зрозумілими та однозначними, тобто таке нормативне регулювання виключає можливість його довільного трактування, тому застосування оскаржуваних положень Закону особами (органами), діяльність яких грунтується на принципі верховенства права, жодним чином не призводить до протиправного позбавлення права власності» (абз. 12 п. 2.3. мотивувальної частини рішення КСУ від 1 липня 2020 року № 7-p(I)/2020) [16].

Такою юридичною позицією КСУ встановив конституційний зміст ч. 1 ст. 88 Закону України «Про нотаріат» у частині диференціації строків звернення до суду фізичних (три роки) $\mathrm{i}$ юридичних осіб (один рік) із вимогами звернення стягувача до нотаріуса за вчиненням виконавчого напису. Цим КСУ вказав на неправильність правової позиції ВП ВС, що загальний строк для звернення стягувача до нотаріуса за вчиненням виконавчого напису не більше трьох років із дня виникнення у стягувача права вимоги до боржника незалежно від суб'єктного складу сторін у правовідносинах, тобто цей строк підлягає застосуванню й у відносинах між юридичними особами [16].

Необхідно зазначити, що забезпечення єдності судового правозастосування у період транзитності законодавства вимагає консолідованої діяльності усіх публічних інституцій України, а не лише судів. Адже конституційний принцип рівності прав передбачає однакове застосування правової норми (абз. 2 п.п. 5.4 п. 5 мотивувальної частини рішення КСУ від 22 вересня 2005 року № 5-рп/2005).

Необхідно навести й іншу позицію КСУ про те, що «складнощі у трактуванні законодавства через його неповноту, неясність, суперечливість чи прогальність не можуть бути підставою для ухилення суду від прийняття рішення по суті справи; однаковість практики застосування законодавства і усунення неоднозначності застосування законодавства судами в їх рішеннях забезпечується шляхом перевірки судових справ у касаційному порядку, узагальнення практики правозастосування Верховним Судом України (абз. 4, 6 п. 3 мотивувальної частини ухвали КСУ від 27 січня 2000 року № 16-у/2000).

Висновки. Аналізуючи постанови ВП ВС та постанови інших підрозділів ВС, можна зробити висновок, що у багатьох справах, рішення в яких можуть мати загальне значення для судової практики, здебільшого постають такі проблеми, які не мають свого розв'язання лише у приписах чинного законодавства та інших джерел, а потребують обгрунтування за допомогою доктринальних засобів та врахування соціальних (позаюридичних) аргументів. Також потребує вирішення законодавче врегулювання виключної проблеми, яку у правовій площині ВС розв'язав, однак ця проблема не зникла.

Зауважуємо на необхідності початку й налагодження неформального діалогу у вигляді певних спільних нарад, а не тільки конференцій, круглих столів тощо, на яких будуть обговорюватися питання забезпечення єдності розуміння правових норм на першому етапі подолання перехідної юстиції в Україні з огляду на кардинально протилежні реформи останніх років. Це обов'язково впливатиме на єдність застосування правових норм як галузевого, так і конституційного розуміння. Тому на такі наради обов'язково мають бути залучені, окрім представників судової влади, представники Парламенту, Кабінету Міністрів України та Конституційного Суду України. Підкреслюємо важливість залучення до неформального діалогу цих органів саме на першому етапі розвитку і впровадження верховенства права в усі сфери повсякденного життя українських громадян.

\section{Список використаних джерел:}

1. Graver Hans Petter. The Judicial Role and the Rule of Law. Nordic Journal Of Human Rights. 2016. Vol. 34, № 3, 222-225. DOI 10.007/978-3-62-44293-7_1.

2. Guidance Note of the Secretary-General. United Nations Approach to Transitional Justice. March 2010. https://www.un.org/ruleoflaw/files/TJ_Guidance_Note_March_2010FINAL.pdf.

3. Nigel Rapport. Distortion: Social Processes Beyond the Structure $\bar{d}$ and Systemic (Routledge Studies in Anthropology) 1st Edition. Routledge; (August 16, 2017), 185 p.

4. Oksana Khotynska-Nor, Lidiia Moskvych and other. Role of Confidence and Supply Chain Strategy during Legitimization of Justice in Countries of Transitional Period. P. 533-534. URL: https://ojs.excelingtech.co.uk/index.php/IJSCM/article/view/4104/2066.

5. Santiso Carlos. "The Elusive Quest for the Rule of Law: Promoting Judicial Reform in Latin America". Brazilian Journal of Political Economy. 23, 2003. № 3. P. 112-134. 
6. Гаудер Пол. Верховенство права в реальному світі. Пол Гаудер. Пер. з англ.: Д. Вовк, В. Гончаров, К. Горобець та ін.; кер. проекту Д. Лученко; наук. ред. Д. Вовк. Харків : Право, 2018. $392 \mathrm{c}$.

7. Berestova Iryna, Khotynska-NorOksana, Kopytova Olena, Bratel Oleksandr, Dronov Serhii. Subordinate Relationship between Civiland Constitutional Legal Proceedingsinthe Countrieswithan Autonomous Body of Constitutional Control. Journal of Legal, Ethical and Regulatory Issues (Print ISSN: 1544-0036; Online ISSN: 1544-0044). Research Article: 2020 Vol: 23.

8. Господарський процесуальний кодекс України в редакції Закону України «Про внесення змін до Господарського процесуального кодексу України, Цивільного процесуального кодексу України, Кодексу адміністративного судочинства України та інших законодавчих актів від 3 жовтня 2017 року № 2147-VIII (зі змінами). URL: http://zakon.rada.gov.ua/laws/show/2147-19/ card6\#Public.

9. Моєсеєнко Д.М. Форма постсоціалістичної держави: поняття, класифікація, тенденції розвитку. Дис. канд. юрид. наук: 12.00.01. Запоріжжя, 2017. 255 с.

10. Постанова Великої Палати Верховного суду від 02 липня 2019 року у справі № 916/3006/17. URL: http://www.ccu.gov.ua/dokument/7-ri2020.

11. Про виконавче провадження : Закон України від 02 червня 2016 року № 1404-VIII. Відомості Верховної Ради (ВВР), 2016, № 30, ст. 542.

12. Про органи та осіб, які здійснюють примусове виконання судових рішень і рішень інших органів : Закон України від 02 червня 2016 року № 1403-VIII. Відомості Верховної Ради, 2016, № 29, ст. 535.

13. Про статус суддів : Закон України від 15 грудня 1992 року № 2862-XII. URL: https://zakon.rada.gov.ua/laws/show/2862-12\#Text.

14. Про судоустрій і статус суддів : Закон України від 10 липня 2010 року № 2453-VI. URL: https://zakon.rada.gov.ua/laws/show/2453-17/ed20100707\#Text.

15. Про судоустрій і статус суддів : Закон України від 02 червня 2016 року № 1402-VIII. (Відомості Верховної Ради (ВВР), 2016, № 31, ст. 545).

16. Рішення Конституційного Суду України (Перший Сенат) у справі за конституційною скаргою товариства 3 обмеженою відповідальністю «Укркава» щодо відповідності Конституції України (конституційності) положень частини першої статті 88 Закону України «Про нотаріат» від 1 липня 2020 року № 7-p(I)/2020. URL: http://www.ccu.gov.ua/dokument/7ri2020?fbclid=IwAR0fGJnlNzMxOIL ZwOLvlk0auyrytw1HzmldKA0M4qjU9Mv912Vdd2AZFRM.

17. Рішення Конституційного Суду України у справі за конституційними скаргами Мельничук Надії Миколаївни, Григор'євої Лілії Іванівни та Кліменко Марини Робертівни щодо відповідності Конституції України (конституційності) положення підпункту 1 пункту 28 розділу II Закону України «Про запобігання фінансової катастрофи та створення передумов для економічного зростання в Україні» від 15 квітня 2020 року № 2-p(II)/2020. URL: http://www.ccu.gov.ua/ $\operatorname{docs} / 3085$.

18. Савчин Михаил. Непрерывность национальной конституционной традиции в условиях вызовов и угроз, или О континуитете. URL: https://zn.ua/internal/nepreryvnost-nacionalnoy-konstitucionnoy-tradicii-v-usloviyah-vyzovov-i-ugroz-ili-o-kontinuitete-253029_.html. 